\title{
A NEXT GENERATION OF INNOVATION MODELS? AN INTEGRATION OF THE INNOVATION PROCESS MODEL BIG PICTURE @ TOWARDS THE DIFFERENT GENERATIONS OF MODELS
}

\section{Benjamin Taferner}

Benjamin Taferner

EU studies in Project management,

Eisenstadt, Austria benjamin.taferner@gmail.com

Article info

Paper category: Review Paper Received: $10.5 \cdot 2017$. Accepted: $8.9 \cdot 2017$ JEL classification: O3 


\begin{abstract}
The competition on every market grows harder and harder every year. Innovation is seen by most companies as the only way to survive. For finding good innovations, innovation processes are needed to implement within the firm. This paper deals with the generations of those models. The first part of the paper lists the different generations described in the literature. In the second part the BIG Picture ( model created by Dipl.-Ing. Dr. Lercher is introduced and compared to the criteria found in the described models. Therefor the aim of this paper is to give the reader an overview of the existing models and an understanding of the classified model. The estimated results were a classification in the current generation. However, the model shows additional criteria which have not been set by any of the review authors. The point, if this model is still a sixth generation model or already a seventh generation model, was let open for discussion in this paper. Methodology includes an analyses of the described generations of the most frequent cited authors and an evaluation of the new model.
\end{abstract}

\title{
Keywords:
}

Innovation models; Innovative milieu; Idea generation; BIG Picture; Closed innovation; Open innovation 


\section{INTRODUCTION}

Cooper wrote 2005 in his book Product Leadership: "It's war: Innovate or Die". Every year innovation becomes not only more vital for the success but also determines a company's very existing. The ability to innovate is one of the core competence needed for an organization to compete in the ever increasing challenging and highly changing environment (Cooper, 2005).

The Boston Consulting Group's annual global report shows this awareness from firms very clearly. For the year of 2015, 79\% of the respondent's ranked innovation as either the top priority or a top three priority (see Table 1.). Since 2009, the importance in a company's agenda for innovation has raised by $15 \%$ (Ringel, M., Taylor, A., \& Zablit, H., 2015).

Table 1.: Importance of innovation in company's agenda

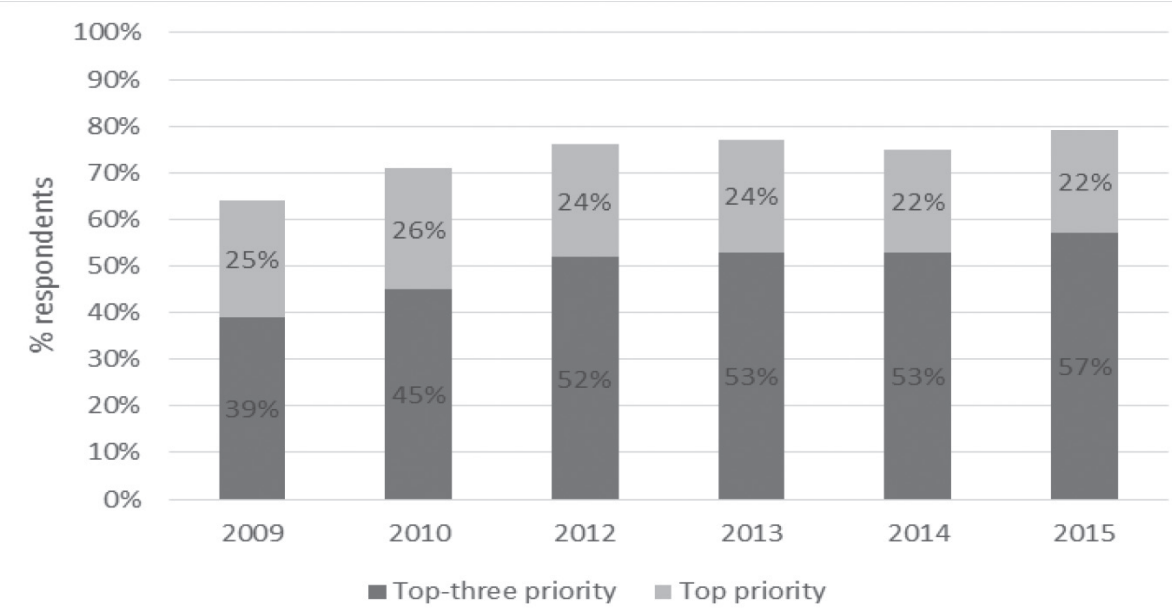

Source: Author's representation based on Ringel, M., Taylor, A., \& Zablit, H. (2015)

For those who are not already part of the top innovation companies the question often remains unanswered, how to be innovative?

\section{BACKGROUND}

Over the last two decades, the literature has described different generations of innovation models. Most of them refer to Rothwell (1994) classification, but there are also other authors who are describing a smaller different classification and titling, as shown in Table 2. Despite the fact that Rothwell (1994) is the oldest, it is still seen as the standard classification, which explains that the other concepts are based on his idea. 
Table 2.: Innovation generation models

\begin{tabular}{|c|c|c|c|c|}
\hline GENERATION & $\begin{array}{l}\text { ROTHWELL } \\
\text { (1994) }\end{array}$ & $\begin{array}{c}\text { MARINOVA } \\
\text { AND } \\
\text { PHILLMORE } \\
(2003)\end{array}$ & $\begin{array}{l}\text { BERKHOUT; } \\
\text { DUIN; ORTT } \\
(2006)\end{array}$ & $\begin{array}{c}\text { BOCHM; } \\
\text { FREDERICK } \\
\quad(2010)\end{array}$ \\
\hline 1 st & Technology push & $\begin{array}{r}\text { The black box } \\
\text { models }\end{array}$ & Technology push & Technology push \\
\hline $2^{\text {nd }}$ & Market pull & Linear models & Market pull & Demand pull \\
\hline $3^{\text {rd }}$ & Coupling model & Interactive model & $\begin{array}{l}\text { Combination of } \\
\text { technology push } \\
\text { and market pull }\end{array}$ & $\begin{array}{r}\text { Portfolio } \\
\text { management }\end{array}$ \\
\hline $4^{\text {th }}$ & Integrated model & Systems model & $\begin{array}{r}\text { Cyclic innovation } \\
\text { model }\end{array}$ & $\begin{array}{r}\text { Integrated } \\
\text { management }\end{array}$ \\
\hline $5^{\text {th }}$ & $\begin{array}{r}\text { Parallel and } \\
\text { integrated model }\end{array}$ & $\begin{array}{r}\text { Evolutionary } \\
\text { model }\end{array}$ & 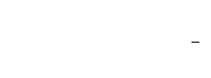 & $\begin{array}{r}\text { Systems } \\
\text { integration }\end{array}$ \\
\hline $6^{\text {th }}$ & - & Innovative Milieux & - & $\begin{array}{r}\text { Integration in } \\
\text { network }\end{array}$ \\
\hline
\end{tabular}

Source: Author's table based on selected authors

\subsection{First generation}

From the 195 os to the middle of the 1960s, rapid industrial expansion and new technology opportunities lead to the belief that more research and development results in successful products (Rothwell, 1994). Figure 1. shows the process for innovation in the first generation.

Figure 1.: First generation innovation model

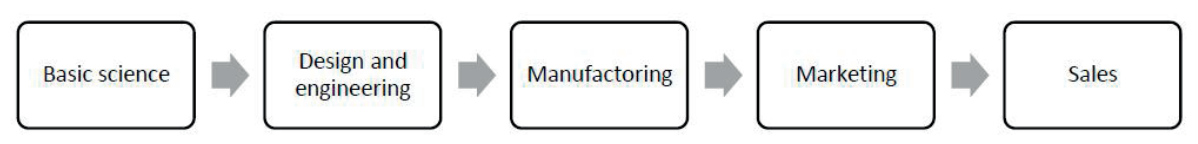

Source: Author's figure based on Rothwell (1994)

\subsection{Second generation}

In the second-generation, middle of 1960 s to early 1970s, the companies within the US had a lot of competition, the employment rate was static and the productivity was increasing. In that time products were developed due to the demand of the market with existing technologies. The market as source of ideas is opposed to the first generation (Rothwell, 1994) and is shown in Figure 2. 
Figure 2.: Second generation innovation model

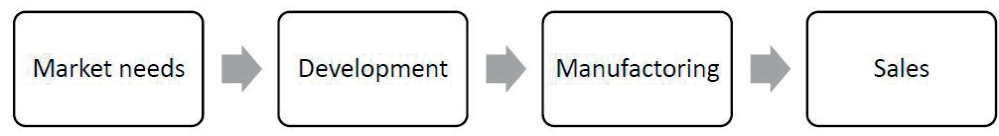

Source: Author's figure based on Rothwell (1994)

\subsection{Third generation}

Bochm and Frederick (2010) call the third generation the portfolio management. The others name it coupling model, interactive model or the combination of push and pull (see Table 2.). Despite the wording all of them describe a model which recognize the influence of technological resources and market needs. As in the models before the process is linear with additional interaction and feedback loops (see Figure 3.).

Figure 3.: Third generation model

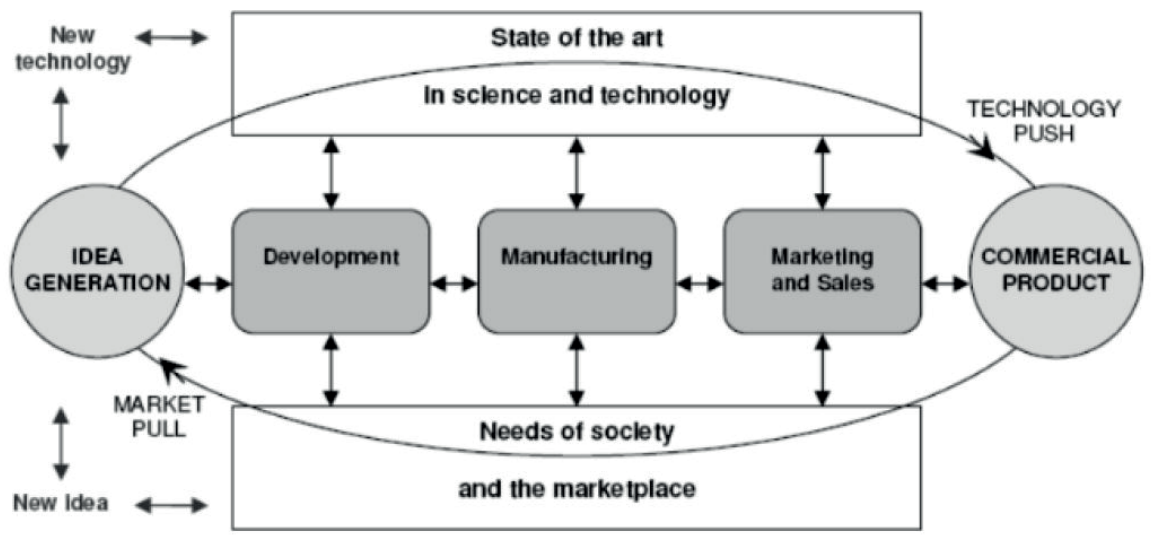

Source: Galanakis (2006)

The Stage-Gate-Process after Cooper (1986) is probably one of the well-known models within the area of innovation management. The model describes a linear process, where each stage is checked on the, in advance set, criteria. If an idea cannot pass a gate, it is sorted out. A newer version of this process (see Figure 4.) splits after the first gate in three different lines, depending on complexity and the risk of the idea (Cooper, 2008). 
Figure 4.: Next Generation Stage-Gate-Process by Cooper

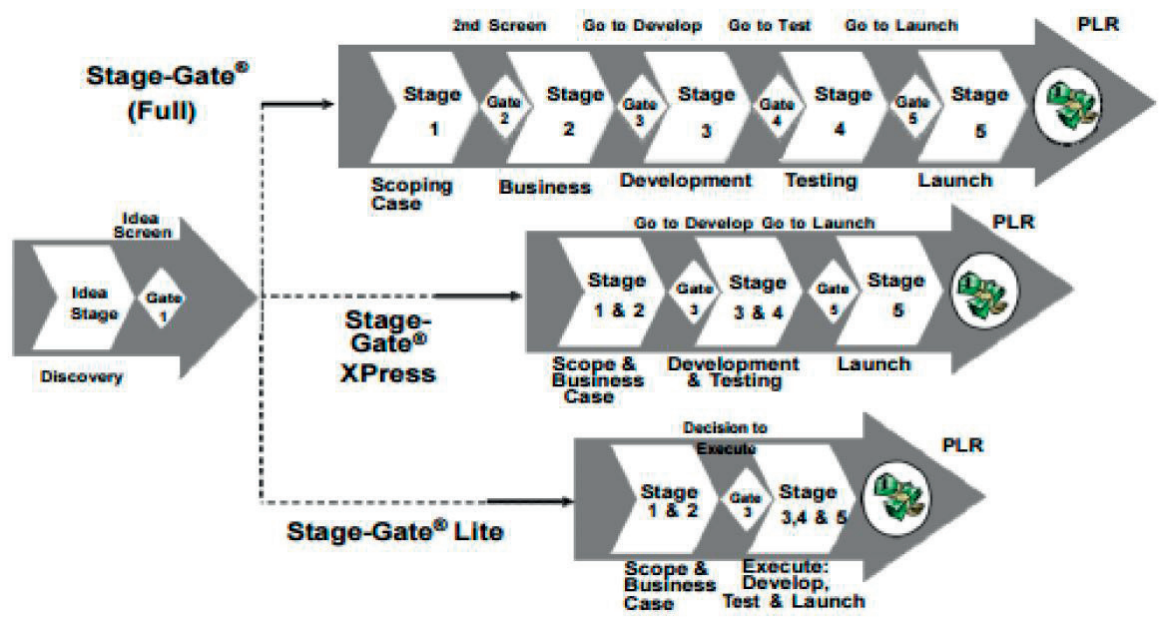

Source: Cooper (2008)

\subsection{Fourth generation}

In the early 1980s, the awareness for strategic planning and forming alliances with other companies grew in the USA. Due to the shortening of the product lifecycles, time based strategies with integration, parallel development were necessary (Rothwell, 1994). Japanese automobile manufacturers were able to reduce the process of developing new cars from $4,-5$ years to under 3 years with the implementation of Simultaneous Engineering (Bochm and Frederick, 2010).

\section{$2 \cdot 5$. Fifth generation}

From the middle of 1990s, the importance for companies are fast innovations. Firms continue to expand their strategic network and are focused on better integrated products and manufacturing strategies, increasing flexibility and adaptability (Rothwell, 1994).

Marinova and Phillimore (2003) describe the fifth generation as an evolutionary model where innovation can be compared to mutations in the field of biology. Their concept is inspired by the evolution theory after Darwin and like in the theory only the fittest, in this case, the innovation survives.

An example for this generation is given in Figure 5., Galanakis (2006) identifies three main processes in his model laying in the center and representing the company itself: the knowledge creation, the new product development and the product success. These three processes are influenced by the internal and external factors. 
Figure 5.: The Creative Factory System Innovation Model

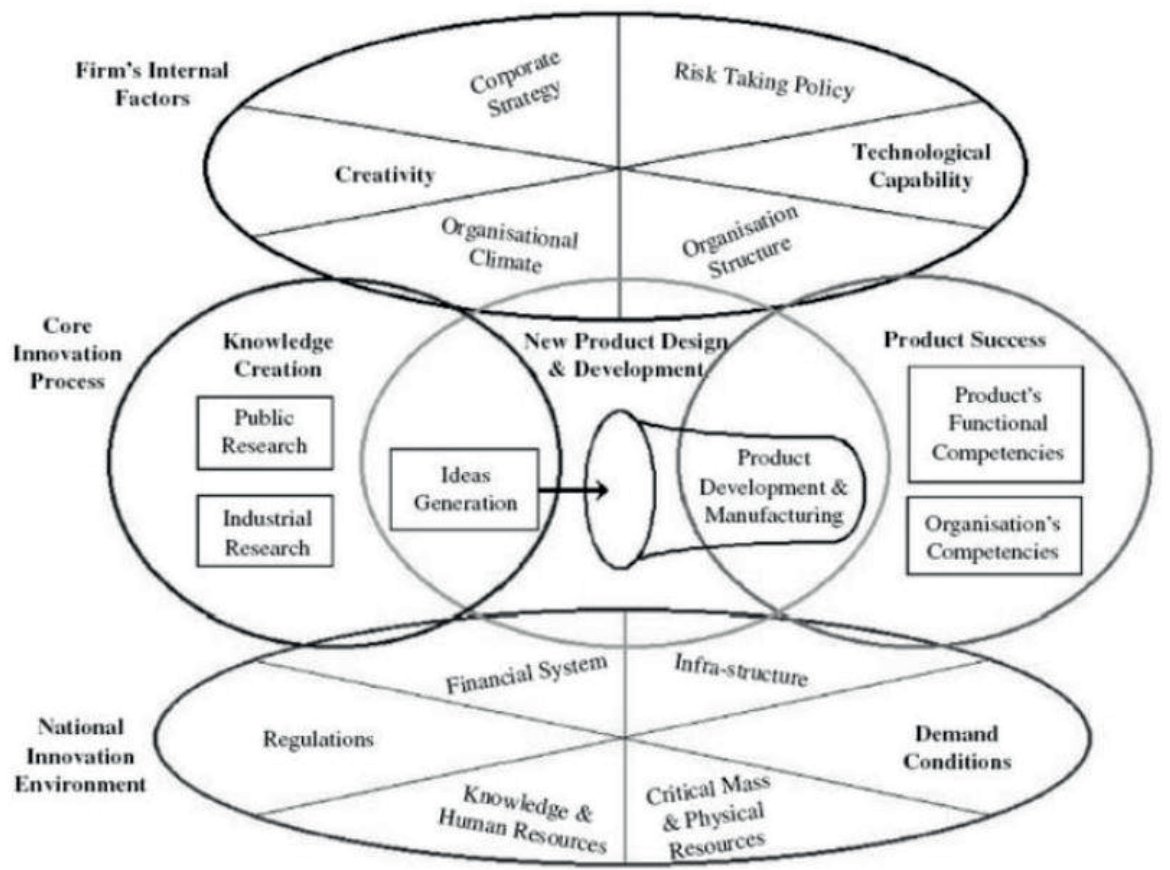

Source: Galanakis (2006)

Even with the influence of the external environment, the fifth generation models are manly closed networks of innovation. This means the innovations are created and developed within the boundaries of the company (Galanakis, 2006).

\subsection{Sixth generation}

The sixth generation requires interaction networks and innovation systems (Bochm and Frederick, 2010). Marinova and Philimore (2003) are consistent with the Integration in network model in these two points. However, the "Innovative Milieux" has as central element the innovative milieu, which is described as combination of knowledge and specific competencies. Additionally, the territorial organization as well as the technical and economic process are key elements. They especially point out that the network is not always formalized in cooperative agreements or contracts. On the contrary, it features the ease of contact and trust between partners and social, cultural and natural conditions (Marinova and Phillimore, 2003).

The described sixth generation models aren't focused on internal ideas or close networks anymore but focus on opening up to the whole market. With this new as- 
pects, ideas can also be generated externally by customer, states or other companies. Figure 6. shows the difference between a closed and an open innovation.

Henry E. Chesbrough wrote in "The Era of Open Innovation" that sooner or later all industries will change from close to open innovation. On the one hand this gives companies the chance to push internal ideas outside, e.g.: start us with own personal for ideas that are not fitting the company's strategy. On the other hand they can pull ideas from the outside inside to commercialize them (Chesbrough, 2003).

Figure 6.: Comparison of closed and open innovation

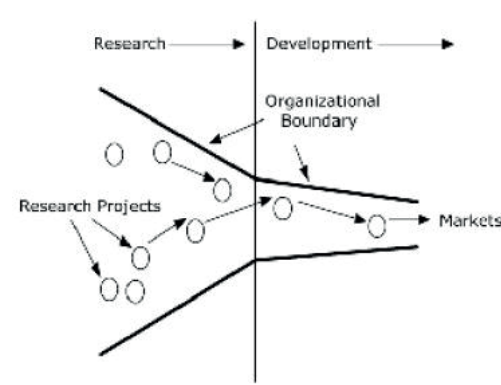

Closed Innovation

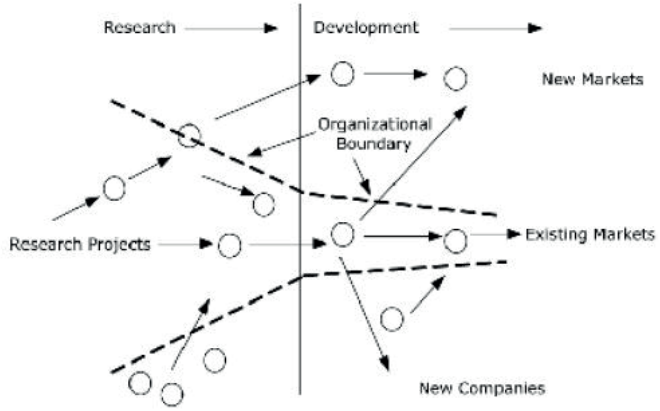

Open Innovation

Source: Binci, D., \& Cerruti, C. (2014)

Focusing on the evolution of the generations, it can be assumed that the next generation will include models which combine the company over all departments with their customers and the geographic conditions, like e.g. government or environment.

\subsection{Criteria found for generations}

The previous section presented the different generation and a few explicit examples. Except for the first two generations, all of them are evolutions of the previous generation. Based on this, I postulate that for new innovation models it is enough to verify if they fulfill all criteria for the 6th generation or if they are still fifth generation models. There is the possibility that a model surpasses the sixth generation criteria, in that case it needs to be discussed if the additionally found criteria are added to the ones of the sixth or if it is necessary to define a seventh generation.

A synthesis of the innovation process models described earlier suggests the following criteria for the sixth generation:

(1) The process includes the following steps:

(a) Idea generation

(b) Concept development and evaluation 
(c) Development

(d) Implementation

(2) The innovation is triggered by a technology push, market pull or a combination of those

(3) Interdisciplinary approach

(4) Organizational and systems integration (including external networking)

(5) Flatter and more flexible organizational structures, including devolved decision making

(6) Feedback loops

(7) Not only focused on product innovation but also service, process, etc.

(8) Implementing life circle view for products.

\subsection{BIG PICTURE @ - The Grazer innovation model}

The BIG Picture (C) model is invented by Dipl.-Ing. Dr. Lercher (2017), as mentioned above. At first glance, it has one big difference to the models described before. Whereas all other models describe a process from A to B, the BIG Picture ( $)$ describes a process from A to B to A (see Figure 7 .). It is an integrated view on innovation processes. The model shows similarities to the Stage-Gate-Process after Cooper. In this model stages are shown as circles and gates as rhombuses. Every gate in the model gives the firm the opportunity to abort the ongoing process. Some paths have more than one line in the model to symbolize the possibility to have more than one ongoing process at the same time.

Figure 7.: BIG Picture $\odot$ model

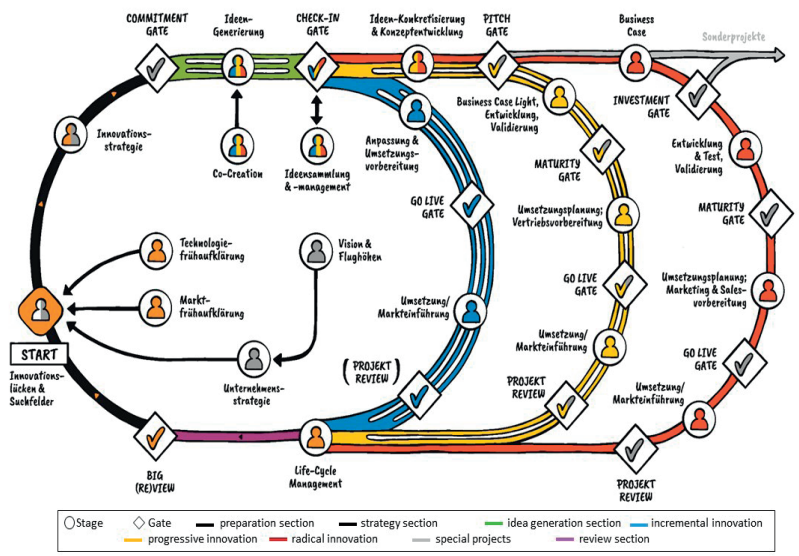

Source: adapted from "BIG Picture (C - Das Grazer Innovationsmodell" by Lercher (2017) 
What is also sticking out is the color code. Table 3 gives an overview on the different paths with their German name, English translation and the color code for the model. The development section is divided into three paths with the color blue, yellow and red. The reason for this is that there are different levels of innovation, from small innovation for the daily business (incremental) to projects with a higher risk and investment but probably no new outcome for the market (progressive) and high risk projects with as possibility to change a lot within the company and also to bring changes on the existing market (radical). An exit line is the gray path for special projects. This path is for disruptive innovations, which will bring a massive change to the market, often even creating a new market.

Table 3.: Segments of the BIG Picture (C)

\begin{tabular}{|c|c|c|c|}
\hline Name in German & Translation & Color code & Sektion \\
\hline Vorbereitungsphase & preparation section & black & $\begin{array}{r}\text { evaluation of the } \\
\text { internal and external } \\
\text { environment }\end{array}$ \\
\hline Strategiephase & strategy section & black & setting strategy \\
\hline Ideenphase & idea generation section & green & $\begin{array}{l}\text { creation and first } \\
\text { evaluation of ideas }\end{array}$ \\
\hline $\begin{array}{l}\text { Umsetzungs- \& } \\
\text { Projektphase }\end{array}$ & development section & blue & $\begin{array}{r}\text { for incremental } \\
\text { innovations }\end{array}$ \\
\hline & & yellow & $\begin{array}{r}\text { for progressive } \\
\text { innovations }\end{array}$ \\
\hline & & red & for radical innovations \\
\hline Sonderprojekte & special projects & gray & $\begin{array}{l}\text { for disruptive } \\
\text { innovations }\end{array}$ \\
\hline Erfolgskontrollphase & $\begin{array}{r}\text { efficiency review } \\
\text { section }\end{array}$ & purple & $\begin{array}{r}\text { controlling, lessons } \\
\text { learned and life circle } \\
\text { evaluation }\end{array}$ \\
\hline
\end{tabular}

Source: Author's representation based on Lercher (2017)

Additionally, Lercher (2017) points out that his model has the following features:

- the innovation strategy is embedded in the model

- with the company's vision and level of view

- own section for finding innovation fields and gaps

- including the necessary source of information

- the four levels of innovation are included

- model is very well structured, especially due to the stages and gates

- own section for efficiency review. 


\section{RESULTS}

The criteria defined earlier are now confronted with the BIG Picture (c) model. Table 4. shows the criteria, if it is fulfilled.

Table 4.: Final results

\begin{tabular}{|c|c|c|}
\hline \multicolumn{2}{|r|}{ Defined criteria } & BIG Picture $\bigodot$ \\
\hline 1 & $\begin{array}{r}\text { process includes idea generation, concept } \\
\text { development and evaluation, development, } \\
\text { implementation }\end{array}$ & $\checkmark$ \\
\hline 2 & $\begin{array}{l}\text { the innovation is triggered by a technology push, } \\
\text { market pull or a combination of those }\end{array}$ & $\sqrt{ }$ \\
\hline 3 & Interdisciplinary approach & $\sqrt{ }$ \\
\hline 4 & $\begin{array}{r}\text { Organizational and systems integration (including } \\
\text { external networking) }\end{array}$ & $\checkmark$ \\
\hline 5 & $\begin{array}{l}\text { Flatter and more flexible organizational structures, } \\
\text { including devolved decision making }\end{array}$ & $\sqrt{ }$ \\
\hline 6 & Feedback loops & $\checkmark$ \\
\hline 7 & $\begin{array}{r}\text { Not only focused on product innovation but also } \\
\text { service, process... }\end{array}$ & $\checkmark$ \\
\hline 8 & Implementing life circle view for products & $\checkmark$ \\
\hline
\end{tabular}

Source: Author's representation

As seen in Table 4. all set criteria are fulfilled. What is necessary at this point is to give a more detail explanation of how they are fulfilled.

The model not only includes this process steps but highlights, as can be seen in the Figure 7 . The green line is solely for the step idea creation and the end of the green line includes a gate for evaluation of the idea. Depending on the kind of innovation the development and implementation process is split between the blue, yellow and red line.

To start the BIG Picture (C) process prior information is required. The user has to have the company strategy and the vision in mind. However, it is also necessary to constantly observe the market and potential new technologies.

The interdisciplinary approach and the organizational \& systems integration are both points to prevent the suffering from a tunnel vision. By including people (internal or external) in the creation process who are not specialized in that topic a different view of the problem can be created, leading to a wider set of possible solutions.

For the BIG Picture (C) model to function correctly it is demanded that while implementing the process every stage and gate needs a defined person, time- and financial frame. While the gates are allocated to specific decision makers, the stages are more open and flexible. For instance a stage like the innovation strategy can be assigned to different departments or employees. 
The BIG Picture (C) includes the feedback loop after every step in the process, shown as the gates. This ensures that the process can be stopped or corrected at all times, preventing a failure at the end of the process.

The model itself doesn't distinguish between the types of innovation. It only gives an overview of how an ideal process should look like. The types of innovation triggered in the stages are depending on the used methods (e.g.: TRIZ for technical solutions).

The model includes a stage for life-circle management. On the one hand to evaluate the done projects and on the other to check in combination with marketand technology research for future innovations.

Further on, there are points found in the model which have not been defined yet:

First of all, the very open description of the model. Innovation process models are often custom designed for specific branches. Which in turn leads to unsuitable usage or at least a lot of work to change the model for a fitting use.

Second, the combination of the strategic and the operative innovation part. Models in the past often only focus on the operative part. However, constantly recurring successful innovations can only be achieved if the company includes the management as strategic and the employees as operative part.

Third, the already mentioned part of not describing a process which runs onetime and then is finished but describing it as never-ending circle.

\section{DISCUSSION AND CONCLUSION}

There are a couple of points still open for discussion before the conclusion.

First, a lot of literature has been reviewed for this paper, but there is still the possibility that relevant papers have been overseen. The reason for this argumentation is the sheer amount of papers available regarding the topic innovation process models. For instance, the topic innovation strategy is often categorized or labeled as management and can be hard to find and match towards innovation.

Second, there can be a lot more authors been found dealing with the written topic. As author of this paper, I had to choose a few of them. Dealing with all of them wasn't also not the aim of the paper. It was to find the most recognized theories and find the criteria described by them.

Third point is the additionally, described points found in the BIG Picture (C) model which could not be harmonized with the set criteria. Related to the first discussion point, it is possible that another author already defined those for the sixth generation and has not been reviewed by this paper.

Relating to the conclusion of this paper, it has been clearly showed that the BIG Picture (C) model is a sixth-generation innovation process model by the set criteria. However, there have been found additionally points which were not correlating with the generation description of the reviewed authors. A reason for this could be, it has 
already been stated before. Another reason could be that they are actually really new for innovation process models. If that is the case, there is a further investigation necessary to clarify if the points need to be added to the sixth-generation criteria or if the BIG Picture (C) model can be seen as first model of seventh generation.

\section{Acknowledgements}

At this point, I want to express my thanks and appreciation to Dipl.-Ing. Dr. Lercher, who not only responded to my mails with questions within minutes but also allowed me to use his work the BIG Picture (c) for this paper. Especially because his book on his model hasn't been published by the time this paper was written. 


\section{REFERENCES}

Berkhout, A. J., Duin, P., \& Ortt, R., Innovating the innovation process. International Journal of Technology Management, (1999): 390-404

Binci, D., \& Cerruti, C., OPEN INNOVATION. MANAGEMENT INNOVATION NEWSLETTER, (2014): 2 http://www.managementinnovation.it/wp-content/uploads/2014/og/MAINNews-n.14.pdf [01.02.2017]

Bochm, G., \& Frederick, L. J., Strategic innovation management in global industry networks. Asian Journal of Business Management, (2010):110-120

Chesbrough, H.E., The Era of Open Innovation. MIT Slogan Management Review, volume 44, no 3, (2003): $35-41$

Cooper, R. G. (1986). Winning at new products. New York: Addison-Wesley Publishing.

Cooper, R. G. (2005). Product Leadership: Pathways to Profitable Innovation. Basic Books.

Cooper, R. G., Perspective: The stage-gate idea-to-launch process - Update, what's new and nexGen Systems. Journal of Product Innovation Management, May 25, (2008): 213 - 232

Galanakis, K., Innovation process: Make sense using systems thinking. Technovation, (2006, 11): 12221232

Lercher, H. (2017). BIG PICTURE DAS GRAZER INNOVATIONSMODELL. Graz: Anzeigen und Marketing Kleine Zeitung $\mathrm{GmbH} \&$ Co KG.

Marinova, R., \& Phillimore, J. (2003). Models of innovation. In V. Shavinina, International handbook on innovation. Amsterdam: Elserver.

Ringel, M., Taylor, A., \& Zablit, H. (2015), 12 (02). Innovation in 2015. https://www.bcgperspectives.com/ content/articles/growth-lean-manufacturing-innovation-in-2015/ [05.02.2017]

Rothwell, R., Towards the fifth-generation innovation process. International Marketing Review, (1994): $7^{-31}$

Tidd, J. (2006). A review of innovation models. Imperial College London, discussion paper 1.

Trott, P. (2005). Innovation Management and New Product Development. Harlow, England: Pearson Education Limited. 